\title{
Meeting global standards for hand sanitizer efficacy: formulation matters
}

\author{
SL Edmonds ${ }^{1}$, DR Macinga ${ }^{1 *}$, P Mays-Suko², C Duley ${ }^{2}$, JW Arbogast ${ }^{1}$ \\ From International Conference on Prevention \& Infection Control (ICPIC 2011) \\ Geneva, Switzerland. 29 June - 2 July 2011
}

\section{Introduction / objectives}

Critical questions have been raised in the scientific literature and by hand-hygiene thought leaders regarding the minimum alcohol concentration that assures efficacy of alcohol-based hand rubs (ABHR). The objective of this study was to determine the relative influences of alcohol concentration and product formulation on the efficacy of ABHR using internationally recognized methods.

\section{Methods}

Eleven commercially available alcohol-based hand rubs (gels and foams) containing between $60-90 \%(\mathrm{v} / \mathrm{v})$ ethanol and WHO-recommended hand rub formulations containing $75 \%$ isopropanol or $80 \%$ ethanol were evaluated in a series of studies. Test methods included EN 1500 (Hygienic Hand Rub) and ASTM E1174 (Healthcare Personnel Handwash).

\section{Results}

Four ABHR ranging from 70-80\% ethanol met EN 1500 requirements with a $3 \mathrm{ml}$ application volume applied for 30 seconds. Nine ABHR and the 2 WHO formulations were evaluated per E1174 at 2-ml application volumes. Of the products tested, only 2 products, a well-formulated $70 \%$ ethanol ABHR gel and well-formulated $70 \%$ ethanol foam, met the U.S. FDA requirements (reductions of $\geq 2 \log _{10}$ after 1 application and $\geq 3 \log _{10}$ after 10 applications). None of the other nine products achieved a $3-\log _{10}$ reduction following the tenth application.

\section{Conclusion}

Product formulation was found to have a greater influence on efficacy than alcohol concentration. Well-

${ }^{1}$ GOJO Industries, Inc, Akron, USA

Full list of author information is available at the end of the article formulated products containing $70 \%$ ethanol, including ABHR foams, can exhibit greater efficacy than products with higher alcohol levels. These results demonstrate that alcohol concentrations in excess of $70 \%$ are neither necessary, nor always sufficient to meeting global efficacy standards.

\section{Disclosure of interest}

S. Edmonds Employee of GOJO Industries, D. Macinga Employee of GOJO Industries, P. Mays-Suko: None declared, C. Duley: None declared, J. Arbogast Employee of GOJO Industries.

\section{Author details}

${ }^{1}$ GOJO Industries, Inc, Akron, USA. ${ }^{2}$ BioScience Labs, Bozeman, USA.

Published: 29 June 2011

doi:10.1186/1753-6561-5-S6-P26

Cite this article as: Edmonds et al:: Meeting global standards for hand sanitizer efficacy: formulation matters. BMC Proceedings 2011 5(Suppl 6): P26.

Submit your next manuscript to BioMed Central and take full advantage of:

- Convenient online submission

- Thorough peer review

- No space constraints or color figure charges

- Immediate publication on acceptance

- Inclusion in PubMed, CAS, Scopus and Google Scholar

- Research which is freely available for redistribution

Submit your manuscript at www.biomedcentral.com/submit
() Biomed Central

\section{() Biomed Central}

(c) 2011 Edmonds et al; licensee BioMed Central Ltd. This is an open access article distributed under the terms of the Creative Commons Attribution License (http://creativecommons.org/licenses/by/2.0), which permits unrestricted use, distribution, and reproduction in any medium, provided the original work is properly cited. 